\title{
MÁCSÁR GÁBOR \\ AZ EGYETEMI LEMORZSOLÓDÁS ELMÉLETI ÖSSZEFÜGGÉSEI ÉS RENDÉSZETI VONATKOZÁSA
}

\author{
macsarekszer@gmail.com \\ Eszterházy Károly Egyetem, Neveléstudományi Doktori Iskola, \\ levelező hallgató, Eger \\ Rendőrségi Oktatási és Kiképző Központ, Képzésirányitási Szervek, \\ Rendőrségi Szabadidö- és Sportcentrum, Budapest
}

\begin{abstract}
Absztrakt
A rendészeti lemorzsolódás egyik legnagyobb problémája, hogy ugyan a Nemzeti Közszolgálati Egyetem rengeteget tesz a diákságért, nincs igazán megfelelő eszköz az intézet kezében a gondosan kiválasztott hallgatók megtartásához. Ennek okán egyre nagyobb igény van az átfogó, összegző kutatási közlemények eredményeire, következtetéseire és ajánlásaira. A megfelelő módszertani elvek alapján elkészített átfogó tanulmányok új megvilágításba helyezik a teljes kutatási területet, így megbízhatóbb lehetőség nyílik a lemorzsolódás aspektusainak feltárására és a problémakör valamennyi érintettjének szempontjából megfelelő megoldások megtalálására. Összefoglaló munkánkban szigorú protokoll alapján elemeztünk és értékeltünk 60 kutatási háttérrel rendelkező színvonalas munkát az elmúlt 5 év vonatkozásában. Az átfogó tanulmány rávilágított, hogy mely területek további vizsgálatára érdemes fókuszálni a lemorzsolódás kutatásait.
\end{abstract}

Kulcsszavak: egyetemi lemorzsolódás, rendészet, rendszerezett irodalmi áttekintés 


\begin{abstract}
One of the biggest problems with law enforcement dropouts is that while the National Civil Service University is doing a lot for its students, there isn't really a proper method in the hands of the institute to keep carefully selected students. As a result, there is a growing need for comprehensive, summary research findings, conclusions and recommendations. Comprehensive studies based on appropriate methodological principles shed new light on the whole field of research, thus providing a more reliable opportunity to explore aspects of dropout and find solutions for all stakeholders. In our summary work, we analyzed and evaluated high-quality work with 60 research backgrounds for the last 5 years based on a strict protocol. The comprehensive study highlighted which areas it is worth focusing on dropout research for further investigation.
\end{abstract}

Keywords: university dropout, law enforcement, systematic literature review

\title{
Bevezető
}

Az elmúlt években a publikációk mennyisége rendkívüli módon megnövekedett a lemorzsolódással kapcsolatban. A különféle orgánumokban megjelenő tudományos minőségű közlemények az internet által elérhetővé teszik az új információt, ugyanakkor az átláthatatlan sürüségú és olykor ellentmondásokkal teli adathalmaz nem könnyíti meg az információk használhatóságát. Mivel lehetetlen lépést tartani az új kutatási eredményekkel, így egyre nagyobb igény mutatkozik a szisztematikus irodalmi áttekintésekre.

Kutatásunk legfőbb célja, hogy az általunk lefektetett módszertani elvek mentén haladva feltárjunk olyan összefüggéseket, amelyek a rendészeti terület lemorzsolódásától eltávolodva, komplex módon, több szempontú megközelítéseket és tágabb látóteret adnak számunkra, továbbá az összehasonlító vizsgálat által közelebb visznek a problémakör feltérképezéséhez és az eredményes megoldások alkalmazásához.

Az összefoglaló munkák, amelyek kritikus irodalmi beszámolónak tekinthetők, reméljük, hasznos információkkal szolgálnak a kutatók számára. Ez a kívánalmunk azonban csak akkor állja meg a helyét, ha az információk logikai felépítése és a következtetések levonása kellően átgondolt, logikai elveknek megfelelő módon kerül rögzítésre. Azok a szerzők, akik nem eléggé nyitottak és objektívek az adatok kezelésében és leválogatásában, számos esetben - természetesen nem szándékosan, - de sajátos módon foglalják össze elgondolásaikat, amivel személyes meggyőződésük és a véleményünkkel egyező adatok leválogatása miatt elveszítik az információk használhatóságát, ami jelentősen torzíthatja a kutatás végeredményét. Az összefoglaló közlemények célja, hogy megfelelő módszertan segítségével, széles spektrumú áttekintő irodalmi tájé- 
koztatást nyújtsanak, és szigorú diagnosztikai protokoll alapján szisztematikus irodalmi áttekintést adjanak a kutatások szintéziséről, amivel további kutatások megindítását segíthetik elö, és a látókör kiszélesedése olyan összefüggéseket világíthat meg, amelyek korábban elkerülték a kutatók figyelmét. (Kamarási és Mogyorósy, 2015)

A lemorzsolódás kapcsán a rendszerezett áttekintő közlemény előnyeinek számbavétele vonatkozásában fontos, hogy az egyetemi lemorzsolódás komplex módon történő vizsgálata széles körü betekintést nyújt a megoldandó problémába. Az elbeszélő összefoglalóktól abban különbözik, hogy az összes tudományos értékű tanulmány szisztematikus legyűjtése által megismételhetővé teszi a kutatás folyamatát és annak eredményeit, ilyenformán bármikor reprodukálhatóságot biztosít, és hasonló eredményekre jut az ismételt vizsgálat is a kutatási módszerek pontos leírása által.

Pusztai Gabriella több kutatócsoport munkájában is részt vett (Kovács et al., 2018; Pusztai, Kovács, Hegedűs, 2019; Pusztai, Fónai, Bocsi 2019; Pusztai, Fényes, Szigeti, 2019), több szempontú kutatómunka jellemzi a területen a Debreceni Egyetemet vagy éppen a Pécsi Tudományegyetemet (Kovács et al., 2018; Engler, 2017; Pusztai, Fényes, Szigeti, 2019). A módszertani összefoglalások közül a lemorzsolódás tekintetében a legjobb elméleti áttekintést összefogó mű Szőllősi Gábor munkája, amely rendkívül jó támpontod ad a témakör megközelítésére. (Szőllősi, 2019)

A Nemzeti Közszolgálati Egyetem az elmúlt időszakban a többi egyetemhez hasonlóan magas lemorzsolódási mutatókkal rendelkezik. Az egyetemi pályaelhagyás problémája égető kérdés az intézmény eredményes működtetése miatt, ezért a rendészeti tagozat vezetése keresi a megoldást erre a komplex problémakörre. A rendészeti lemorzsolódás összefüggéseinek feltárásában felmerült a kompetenciák kérdése (Németh és Hegedűs, 2014) és a kiválasztás témaköre (Mogyoródi, 2016; Miskolci, Bársony és Király 2018; Márton, 2018), vagy az, hogy osztályfőnöki rendszer vagy a mentorálás a hatékonyabb a hallgatók perzisztenciájában (Sipos, 2018).

Célunk továbbá, hogy az egyetemi lemorzsolódás és a rendészet összefüggéseit vizsgálva megtaláljuk azokat a hangsúlyos pedagógiai természetú elemeket, amelyek összefüggésbe hozhatóak a rendészeti szakterület problémakörével, és ennek mentén megoldást nyújthassunk a rendészeti egyetemi lemorzsolódás kezelésére.

\section{Módszer}

A kutatással kapcsolatos torzító hatás kiküszöbölése és a kutatás reprodukálhatósága érdekében előre meghatározott kritériumrendszer alapján válogattuk be a tanulmányokat összefoglalónkhoz. Ezen protokoll segít a kutatást céljának fókuszban tartásában, valamint abban, hogy az irodalom keresése megismételhető folyamat legyen. A módszeresen kiválasztott tanulmányok kritikus 
elemzés és értékelés alá kerülnek. Kutatásunk során kizárólag olyan müveket dolgoztunk fel, amelyek tudományos igényességgel összeállított és feldolgozott anyagok voltak, pl. tanulmány vagy tanulmánykötet, lektorált szakanyag, szakcikk, Országos Tudományos Diákkör versenyére készített cikk, konferenciaabsztrakt, konferenciatanulmány, valamint szakértői összegzés.

Keresőmotorként a Google-t és a Google Tudóst alkalmaztuk. Az adatgyűjtéshez az egyetemi lemorzsolódás és a felsőoktatási lemorzsolódás kifejezéseket használtuk, amelyekre mintegy 1100 db találatot adott a Google. Finomításként beállítottuk, hogy csupán a 2015 és 2020 közötti anyagokat kínálja fel a webes felület. Mivel azonban még mindig túl sok anyagot kellett volna feldolgoznunk, úgy határoztunk, hogy a tanulmányok kiválasztásában az első 5 oldal (oldalanként tíz) anyagát veszünk górcső alá. A nem megfelelő tudományos igénnyel készített cikkeket kiszelektáltuk. A tanulmányköteteket, tudományos előadások absztraktjait és szimpóziumok anyagait szerzők és kutatási eredmények szerint dolgoztuk fel. Az anyagokat áttanulmányoztuk, és a legfontosabb eredményeket Excel táblázatban rögzítettük az áttekinthetőség és könnyebb feldolgozhatóság érdekében. A rögzítés módja szerző, kiadás dátuma, címe vagy tartalma, minta, módszer, eredmény, ajánlások, múfaj. A Google Tudós segítségével ugyanezen elvek mentén a rendészeti lemorzsolódás és az egyetemi rendészeti lemorzsolódás szóösszetételeket keresőkifejezésként alkalmazva 5 találati oldalon vizsgáltuk meg és rögzítettük a találatokat. Ezt követően metaszintézisnek vetettük alá a rendszerezett adatokat, mivel ebben az esetben az adatok kvantifikálására nem volt mód, ezért szöveges összegzést alkalmaztunk. Az egyetemi szintű lemorzsolódás összefüggéseinek feltárását követően az általános érvényű módszerektől és eredményektől haladtunk a rendészeti specifikáció felé. A rögzített adatokat ezután témák és kutatási eredmények alapján csoportosítottuk és válogattuk, majd értékeltük.

A leírtak alapján áttanulmányozott írásmúvek heterogén összetétele, a vizsgált minta reprezentativitásának hiánya és számos kutatásmódszertani hiányosság miatt eltérő megítélése lehet korlátja tanulmányunknak.

\section{Eredmények}

Az eredmények bemutatását a polgári egyetemek lemorzsolódásának megközelítésével kezdem, majd azt követően a rendészeti specifikum vizsgálatát prezentálom, és végül a kétféle megközelítést és kutatói eredményeket hasonlítom össze.

A kutatásunk eredményeként mintegy 60 kutatói anyagot dolgoztunk fel az egyetemi lemorzsolódással összefüggésben. A kutatók/kutatócsoportok által alkalmazott módszerek között a legnagyobb arányban a kérdőíves kikérdezést 29 esetben alkalmazták, ezen kívül dokumentumelemzést, interjút, tartalomés adatbázis-elemzést, mintázatvizsgálatot végeztek, továbbá szakmai konfe- 
renciakiadványokkal, összefoglalókkal próbálták azonosítani és feltárni a probléma forrását.

A munkák föleg részterületek feltárását célzó kisebb tanulmányok, pilotkutatások, olykor konferencia-előadás anyagai, de találunk köztük recenziót, OTDK-dolgozatot, munkacsoportanyagot, továbbá tanulmánykötetet vagy átfogó összegző tanulmányt is.

Hazánkban az egyetemi lemorzsolódás fogalomkörének kutatása az egyetemi expanzióhoz köthető. Nincs közösen elfogadott álláspont a lemorzsolódás megítélésével kapcsolatosan, továbbá a témakör megközelítése sem egységes. Hiányosak és pontatlanok a fogalommeghatározások, ami szintén nem könnyíti meg a terület problémaköreinek behatárolását és ezáltal a problémamegoldás lehetőségeinek feltárását sem. (Magné, 2015; MRK, 2016; Engler, 2017; Miskolci, Bárány, Király, 2018; Pusztai, 2019; Józsa, 2019)

A kutatók valamennyien egyetértenek abban, hogy a felsőfokú lemorzsolódás témaköre komplex, összetett problémakör, mely több szempontú megközelítést és vizsgálatot követel a kutatóktól, kutatócsoportoktól. Eddigi vizsgálataink azt mutatják, hogy valóban összetett vizsgálatokra van szükség.

Számos kutató egyetért abban, hogy a motiváció témaköre mind hallgatói, mind pedig oktatói és egyetemi vezetési szinten is kikerülhetetlen vizsgálati terület. Véleményem szerint a lemorzsolódással kapcsolatos kutatás egyik kulcsterülete szorosan összefügg a külső és belső motiválás témakörével. A motiváció szoros összefüggésben áll a célok témakörével, amely így szintén megkerülhetetlen és vizsgálandó fogalomként jelentkezik a témában. (Lukács és Sebő, 2015; Csók és Hrabéczy, 2019; Józsa, 2018; Németh, 2018; Tóth, 2015; Kovács, 2019; Pusztai, Fónai, Bocsi, 2019; Magasvári és Szabó, 2019; Dunai, 2013; Mogyoródi, 2016; Márton, 2018; Miskolci, Bársony, Király, 2018)

Az egyetemek szempontjából az érdeklődők (leendő hallgatók) irányában rendkívül fontos a pontos tájékoztatás és az eredményes pályára irányítás, a „pályaorientáció", valamint a felvételi eljárást megelőző középiskola típusa. Pl. gimnázium, szakközépiskola vagy szakiskola. (Tóth, 2015; Szigeti, 2020; Hegedűs, 2018)

A kutatók egy része a hallgatói perzisztencia egyik legfontosabb kérdésének a tanulmányi okokat, a pedagógiai módszerek optimális megválasztását, a tanulási módok alkalmazását, továbbá a korábbi hiányosságok (pl. szövegértési, olvasási és tanulásmódszertani ismeretek) meglétét tartja. Itt jelenik meg többek közt a modern pedagógiai elvek és módszertanok alkalmazásának témaköre. (Lukács és Sebő, 2015; Lendvai, Panyor, Hampel, 2019; Fényes, 2018; Kovács, 2018; Pusztai, Fónai, Bocsi, 2019; Hegedűs, 2018; Márton, 2018)

Több kutatás foglalkozik a gazdasági okok és nehézségek vonatkozásával, ami szintén visszavezethető a társadalmi státuszra és a családi háttérre. Az anyagi terhek egyaránt megjelennek állami, intézményi, családi és egyéni szinten is, ami a társadalom teljes vertikumára kihat. Ennek okán valamennyi érintett szereplő érdekelt az egyetemi képzés eredményességében. (Váradi, Demeter, Kovács, 2019; MRK, 2016; Ceglédi, 2019; Alter, 2019; Szőllősi, 2019; 
Pázmány, 2018; Sipos, 2018; Hegedűs, 2018; Dusa, 2019) Ez a rizikófaktor érinti a rendészeti területet is.

A gazdasági kérdéskör következményeként a hallgatók egy része kénytelen munkát vállalni egyrészt az önköltséges tanulmányok finanszírozása, valamint a jobb életminőség biztosítása érdekében. Ennek a folyamatnak a túlsúlyba kerülése és a munkaerőpiac elszívó hatása következményként vehető figyelembe. (Kovács, 2018; Pusztai, 2019; Józsa, 2019 Váradi, Demeter, Kovács, 2019; MRK, 2016; Tóth, Ceglédi, Kovács, 2019; Lendvai, Panyor, Hampel, 2019;)

Az egyik jelentős lemorzsolódási tényezőként a családi háttér jelenik meg, ami egyrészt összefügg a szülők iskolai végzettségével, ezáltal a tanuláshoz való viszonyulással, másrészt mivel a szülők törekvéseivel szemben áll „személyes példájuk", ezáltal a hallgatók nem tudnak azonosulni az előrevetített "kérdőjeles" előnyökkel. Ez nyilvánvalóan összefügg a tanulási szokásokkal és a személy szempontjából optimális tanulásmódszertan alkalmazásával is. Összefügg továbbá a szülői példa és minta másolódásával. Itt említhető meg a generációs problémakör, azaz hogy a digitális térben könnyedén mozgó generáció gyorsan kíván előrejutni, tanulni, tapasztalatot szerezni minden téren, ami megköveteli az online tananyag dinamikus fejlesztését, az információ digitális elérésének lehetőségét és a személyes oktatást kiegészítve a digitális tér oktatók általi rugalmas és rutinszerü felhasználását, tehát összefüggésben van a tanárok, oktatók képzésével is. Itt említhető meg egy másik összefüggés, amely a nyelvismerethez is kapcsolható, hiszen a nyelvtanulás költségei, különórák és oktatók alkalmazása jelentős terheket rónak a családokra. (MRK, 2016; Váradi, Demeter, Kovács, 2019; MRK, 2016; Ceglédi, 2019; Alter, 2019; Szőllősi, 2019; Pázmány, 2018 Pallay, 2019; Dusa, 2019; Sipos, 2018; Hegedűs, 2018, Pusztai, Fónai, Bocsi, 2019; Kristóf, 2019)

A kutatók egy része a megkapaszkodás nehézségét a családi háttér és származás oldaláról közelíti meg, és ebből az aspektusból felmerül a hátrányos helyzet, a társadalmi státus, a szülők foglalkozása, valamint az elsőgenerációs értelmiség rizikófaktora. (MRK, 2016; Pallay, 2019; Ceglédi, 2019; Dusa, 2019; Sipos, 2016; Hegedűs, 2018)

A lemorzsolódás tekintetében mindössze három kutatás foglalkozott a leginkább veszélyeztetett időszak megállapításával és behatárolásával, pedig ha ezt az időszakot figyelembe véve célzottan kapnak segítséget a hallgatók, nagyobb esélyük lehet az inkorporációra. (Doung, 2016; Sipos, 2016) A hallgatók mentorálása (choaching) szorosan összefügg a monitoringrendszer működtetésének személyes kontextusával. Néhány kutató és munkacsoport kifejezetten ajánlja ennek alkalmazását, sőt néhány egyetem eredményesen alkalmazza is ezt a hallgatói támogatást. (MRK, 2016; Csikósné, 2019)

Fontosnak tartjuk az egyetemek tekintetében a specifikumok figyelembevételét. A lemorzsolódás ugyanis részben összefügg az oktatásmódszertani hiányosságokkal. (Hegedűs, 2018; Márton, 2018)

Az intézmény és az intézményfenntartó nem fordít kellő figyelmet az egyetemi oktatók képzésére, az oktatók lemorzsolódására. A régóta várt és 
elmaradt, szükségszerü megbecsülési rendszer reformja is várat magára. Az egyetemi tanárok javadalmazási rendszere elmarad a középiskolai tanárok szintjétől, ami jelentős feszültséget és tanárhiányt okoz. (Rácz, Bebesi, 2013) Ez logikusan, látens módon ugyan, de hosszabb távon kihat többek között a tanárdiák viszonyra. (Váradi, 2019; Várhelyi-Nagy, 2018)

Hiányosságként állapítható meg, hogy a hallgatók véleménye nem jelenik meg markáns módon az eddigi kutatásokban. A lemorzsolódott, egyetemet elhagyó polgárok monitorozása elmarad, holott az intézmények érdekeivel egyezik a hallgatói nyomonkövetés. (Pallay, 2019) Ahol mégis, ott a generációs problémakör felé viszik el a kérdést (Márton, 2018).

Egy másik kérdéskör a felvételi szűrő szükségességének kérdése (jó, rossz, kell, nem), mivel a középiskolákból hozott tudás, ami az oktatás és értékelés összefüggéseiben vizsgálandó, elég heterogén képet mutat, így a felvételi szűrő szükséges és jónak mondható, hiszen a megfelelő kiválasztáson átesett, jó képességü hallgatók nagyobb arányban tudnak megfelelni a felsőoktatási színvonalának. (Németh, Hegedűs, 2014; Pusztai et al., 2019)

A nagyobb vizsgálati tapasztalattal rendelkező kutatótanárok, akik egy kutatói csoport munkáját vezetve állítanak össze kiváló minőségü tanulmánykötetet egy témában, átfogó képet nyújtanak, és számos aspektusból történő vizsgálati eredményeket közölnek. Ilyen a Debreceni Egyetem munkacsoportja által összeállított, 2018-ban készült (Lemorzsolódott hallgatók 2018), Kovács Klára és mtsai. által készített tanulmánykötet, amely 32 magyar és 5 külföldi egyetem lemorzsolódási kutatását foglalja magába. (Kovács et al., 2019) Ugyanilyen nagyszerü munka a 2016-os MRK munkacsoportjának összefoglalója, amely 22 egyetem vezetői közreműködésével keresi a kieső hallgatók problémakörének megoldásait. (MRK, 2016)

A témában korábban született összefoglaló munkák megkísérlik a hazai és külföldi tapasztalatokat összegezni, ajánlásokkal és megoldásokkal élnek a problémakörök kezelésének tekintetében. Ezen művekben megjelennek a nemzetközi felsőoktatási célok, szakképzési irányok, a bejutás, bennmaradás és eredményesség témaköre, a társadalmi hatásmechanizmusok összetevői éppúgy, mint a vallásosságot vagy a nyelvtudást és a lemorzsolódás mintázatait vizsgáló tanulmányok. Egyetemi eredményességnek azt a produktumot tekinthetjük, amely az oktatás által a bemeneti állapothoz képest többlettudásként jelentkezik a kimenet, tehát az egyetem elvégzésének időpontjában. (MRK, 2016; Magné, 2015; Tóth-Bakos, Tóth, 2018; Ped. Konf. ONK, 2019; Váradi, Demeter, Kovács, 2019; Demeter, Karászi, 2018; Markos, 2019; Kovács, Váradi, 2019)

A sport és a civil szervezeti tagság, mint az önkéntes munka vagy a Hallgatói Önkormányzat szervezetében való tevékenykedés, pozitívan befolyásolja a hallgatók egyetemi inkorporációját, ahogyan a csoportos tevékenységek megkötő hatása érvényesül és hat az egyének lelki és fizikai stressztűrő képességére és kötődésére. (Kovács, 2018) Szőllősi Gábor a lemorzsolódást vizsgáló elméleti modellek áttekintő jellegü, összefoglaló tanulmányát adja. Nagyszerüen 
bemutatja a nemzetközi trendek irányvonalait és a témakör megközelítésének képviselői által eddig alkalmazott modelleket és azok fejlődését. (Szőllősi, 2019) Az egyetemi hallgatók nemi összetétele érdekes összetevő, hiszen az elmúlt 10 év vonatkozásában végzett kutatás alapján a nők majdnem kétszer annyian végeznek a felsőoktatásban, mint a férfiak. (Demeter, Karászi, 2018, Pusztai et al., 2020)

Még ez idáig egyetlen kutatás sem tesz említést az egyetemi oktatói kar munka-pihenés-megújulás vizsgálatának viszonyára, ami áttételesen ugyan, de hatással lehet a lemorzsolódás folyamataira.

\section{Rendészeti kutatások eredményei}

A lemorzsolódás és a rendészet összefüggései tekintetében felmerül a pályaorientáció kérdése és annak hatékonysága, a fizikai, motoros képességeknek való megfelelés, a mentorálás szembeállítása az osztályfőnöki rendszerrel, a felvételi eljárást megelőző egyetemi tájékoztatás rendszere, továbbá a motiváció témaköre, az oktatók pályaelhagyása, az új generációk kihívásai és elvárásai, a vezető kiválasztása és a rendészeti kompetenciák, valamint a pedagógiai szemléletformálás és értékelés, végül a nemzetközi kitekintés. A cikkek tekintetében 4 db korábbi múvet (2011, 2014, 2 db 2013-as) is beválogattunk a feldolgozásba, mivel elég szerény a szakirodalom a rendészeti téren.

Néhány gondolat erejéig vegyük sorra az imént olvasott problémaköröket.

1. Pályaorientáció kérdése és annak hatékonysága akkor tudna hatékonyan működni a képzés, ha egy jól működő minőségbiztosítási rendszere lenne. Az alapkiképzés a rendészeti tagozat vezetése szerint egy szükséges folyamat, ami a pályaalkalmasság része. Ha a lemorzsolódókat vesszük egy nagy halmaznak, akkor annak részhalmaza a kiégés és kiábrándulás miatti pályaelhagyók köre. A lemorzsolódás lehet végleges vagy időleges. Ha valaki visszatér a rendészeti hivatáshoz, akkor részlegesen, ha többé nem kerül vissza, akkor véglegesen lemorzsolódott. Érinthet hallgatót és oktatót is. A fogalmat kezelhetjük pozitívumként, hiszen a legjobbak maradnak a rendszerben. Kezelhetjük negatívumként, hiszen jó képességú hallgatóktól esik el a szakma. Ugyanakkor kezelhetjük semleges előjellel, ami szerint a kiválasztódás folyamatának része, és ugyan veszteséggel jár, de a haszon, melyet a „bennmaradó” kiválóságok által nyer a hivatás, ennél nagyobb. Az a felelősségteljes hozzáállás, és személyes elvárásaink is azok, hogy csak a legkiválóbbak képviseljék a rendészeti vezetés magas szintjeit. (Mogyoródi, 2016; Miskolci, Bársony, Király, 2018)

2. A fizikai, motoros képességeknek való megfelelés kapcsán az értékelési rendszer diszkriminatív hatása figyelhető meg, ami hátrányos helyzetbe hozza a férfiakat. A kondicionális képzés szükségszerü a rendészeti hivatás hatékony ellátása és a stressztűrő képesség, valamint a hektikus munkaterhelés szem- 
pontjából. (Detre-Tibenszkiné, 2011; Várhegyi-Nagy Ildikó, 2018)

3. Elemzés tárgya a mentorálás szembeállítása az osztályfőnöki rendszerrel (Sipos, 2019). Molnár Katalin a motivációnak és a szöveges értékelésnek a pedagógiában alkalmazható módszereit fejti ki írásában. (Molnár, 2018)

4. A felvételi eljárást megelőző egyetemi tájékoztatás rendszere, hasonlóan a polgári képzésekhez, a rendészeti területen is jelentős szerepet kap, ugyanakkor gyakorlati hatékonysága még mindig nem a szakmai elvárásoknak megfelelő. (Mogyoródi, 2016, Márton, 2018)

5. A motiváció témaköre, egyéni, családi és oktatói vonatkozásainak jelentősége több rendészeti kutató munkájában megjelenik. A motiváció fókuszának középpontjában az egyetem szakterületeinek igényeinek és a hallgatók egyéni igényeinek megismerése áll. Ezek ismeretének tükrében a képzés közös irányvonalak mentén történő kialakítása vezethet eredményre a lemorzsolódás csökkentése érdekében. (Dunai, 2013; Hegedűs, 2018; Márton, 2018; Magasvári, Szabó, 2019)

6. Az oktatók pályaelhagyása a rendészeti pályát ért átalakulások, az új szolgálati törvény bevezetése és az oktatói munka nyugdíjidőszakot követő szabályozása kapcsán determinálódott. (Rácz, Bebesi, 2013)

7. Az új generációk kihívásai és elvárásai a közelmúlt kutatásaiban az X és Y generációk sajátosságainak vizsgálatával szerepelnek. Az új generációk tulajdonságaira jellemző, hogy: okosak, éles eszűek, könnyen váltanak, nyelveket beszélnek, rugalmasak, rutinosan mozognak a digitális térben, terhelhetőek, sok odafigyelést igényelnek, tehát az oktatók felelőssége nagy. (Márton, 2018; Magasvári, 2019)

8. A vezetőkiválasztás és a rendészeti kompetenciák témakörét kutatók a magyar viszonyokat a nemzetközi trendekhez és kutatási anyagokhoz igazítva alakítottak ki 12 vezetői kompetenciát. (Németh et al.,2014)

9. A pedagógiai szemléletformálás és értékelés vonatkozásában is született néhány tanulmány. Az egyetemek rendelkeznek a megfelelő modern oktatási elvekkel, eszközökkel és módszerekkel, amelyek alkalmazása szintén csökkentheti a lemorzsolódás mértékét. (Molnár, 2018; Márton, 2018; Hegedűs, 2018)

10. A nemzetközi kitekintés (Mogyoródi, 2016) mind a felvételi eljárás, mind pedig a hallgatók megtartásának szempontjából fontos. (Németh et al., 2014) A rendészeti szakterület kapcsolódása a nemzetközi kutatások, tapasztalatok tekintetében az, hogy a középfokú nyelvvizsga már bemeneti (felvételi) követelményként szerepel, a nemzetközi egyetemi szakképzési irányokhoz való idomulás (bolognai folyamat), vagy akár az eredményesség.

11. A rendészeti szabályozók, törvények, rendeletek, utasítások jelentősen befolyásolják a szakmai kiválasztás rendszerét, az egyetemi tanulmányok irányelveit és a teljes karrierív lehetőségeit. Véleményünk szerint jól szabályozott az NKE oktatási környezete. (Rácz, Bebesi, 2013; Márton, 2018) 
12. A rendészeti szakmákra jelentkező női hallgatók aránya is pozitív változást mutat. A rendészeti szakokra felvételt nyert női hallhatók közel 40\%-ot tesznek ki. (Mácsár, Bognár, Plachy, 2020)

13. Meglátásunk szerint a lemorzsolódás egyfajta felsőoktatásból való kiábrándulás is, ami arra utal, hogy nem azt kapja az érdeklődő, mint amit az egyetemi képzéstől várna, tehát a szolgáltatás színvonala és módja nem egyezik az egyén általi elképzelésekkel, melyet néhány kutatás eredménye is alátámaszt. (Ceglédi, 2019; Józsa, 2019; Szőllősi, 2019) Ez ugyan a rendészeti cikkek vonatkozásában nem jelenik meg konkrétan, azonban összefüggések formájában felfedezhető.

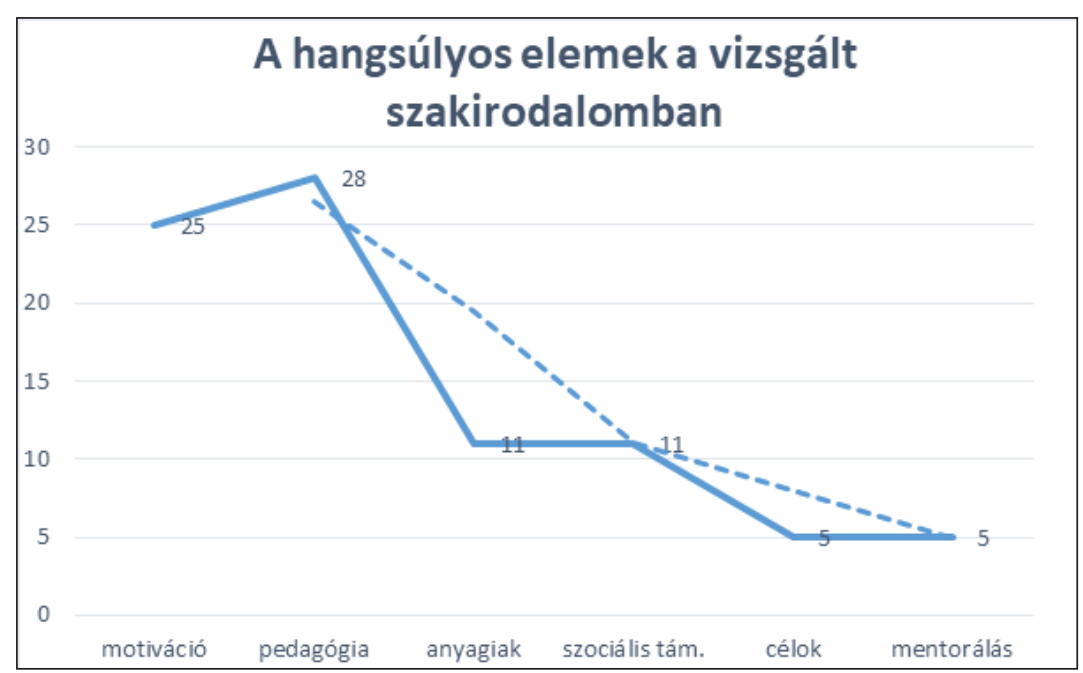

1. sz. diagram

Az 1. sz. diagram a kutatás során feltárt hangsúlyos elemek tartalmát világítja meg számunkra, melyek közül a leginkább kiemelkedő a pedagógiai és motivációs vizsgálat, amely szorosan összefügg a felsőoktatási lemorzsolódással. A kutatott témák közül hangsúlyos az anyagiak és a szociális támogatás kérdésköre, ami a családi, baráti és egyéb társas kapcsolatok támogatására utal. Az érdekesség számunkra az, hogy bár a motiváció rendkívül hangsúlyos elem az összegző szakirodalomban, a célok kérdésköre mégis rendkívül alacsony értéket mutat. Ugyanez mondható el a mentorálásról is, ami közvetve összefügg mind a célokkal, mind pedig a motivációval, de a pedagógiával is.

A leválogatott cikkek, tudományos igényű szakanyagok az anyagfeldolgozás módját tekintv nyolc csoportba sorolhatók. 


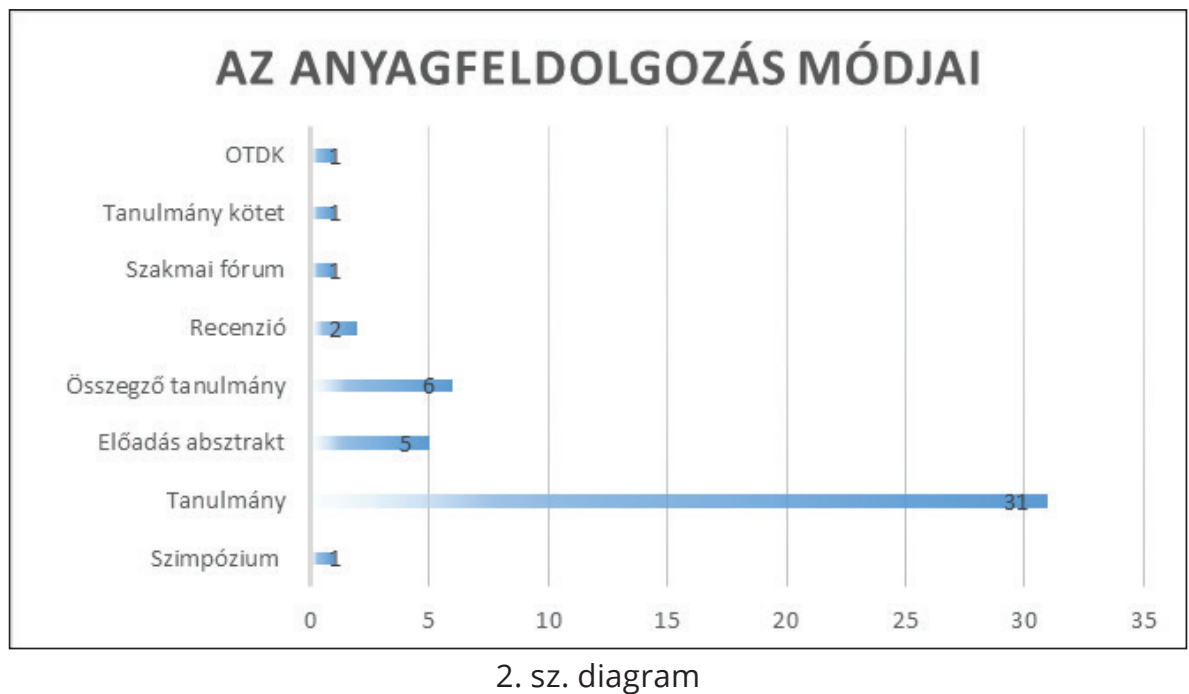

A 2. sz. diagram azt mutatja meg számunkra, hogy kiemelkedő számban a tanulmányok szerepelnek az összegzésben (31 db), míg a tudományos áttekintő, összegző tanulmányokból $6 \mathrm{db}$, illetve az előadásabsztraktokból 5 db szerepelt. A továbbiakban az anyagfeldolgozás tekintetében egy-két módszer volt jellemző.

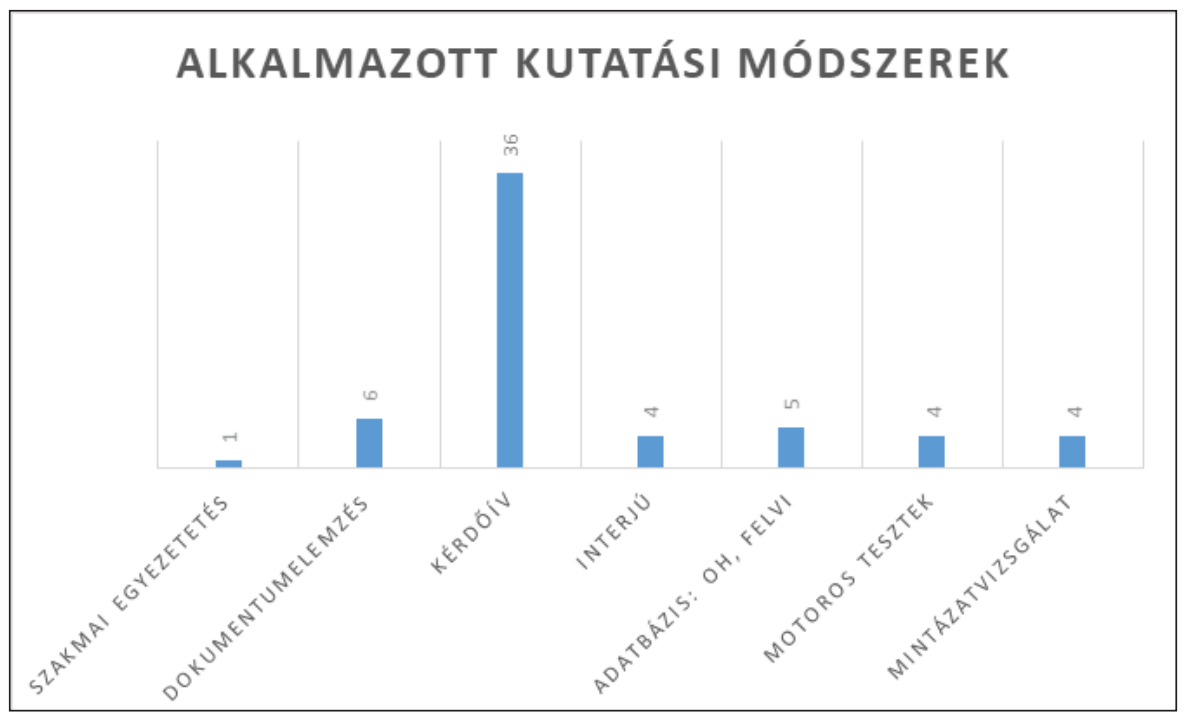

3. sz. diagram

A 3. sz. diagram a kérdőíves kutatási módszer szignifikancia életmód adja meg számunkra a többi alkalmazott kutatási módszerrel összefüggésben. 
Maga a lemorzsolódás megítélése is megosztja a kutatókat és oktatókat, hiszen vannak, akik úgy ítélik meg, hogy egyértelmúen rossz, vannak, akik pedig egy szükséges és kívánatos folyamat, a kiválasztás részeként tekintenek a témára. A gyakorlat próbájaként kezelik az intézmény elhagyását. (Márton, 2018; Miskolci, Bárány, Király, 2016) A tanárok véleménye is megoszlik ezen a téren, hasonlóságot tapasztaltunk, amit egy korábban rögzített interjús vizsgálat kapcsán rögzítettünk.

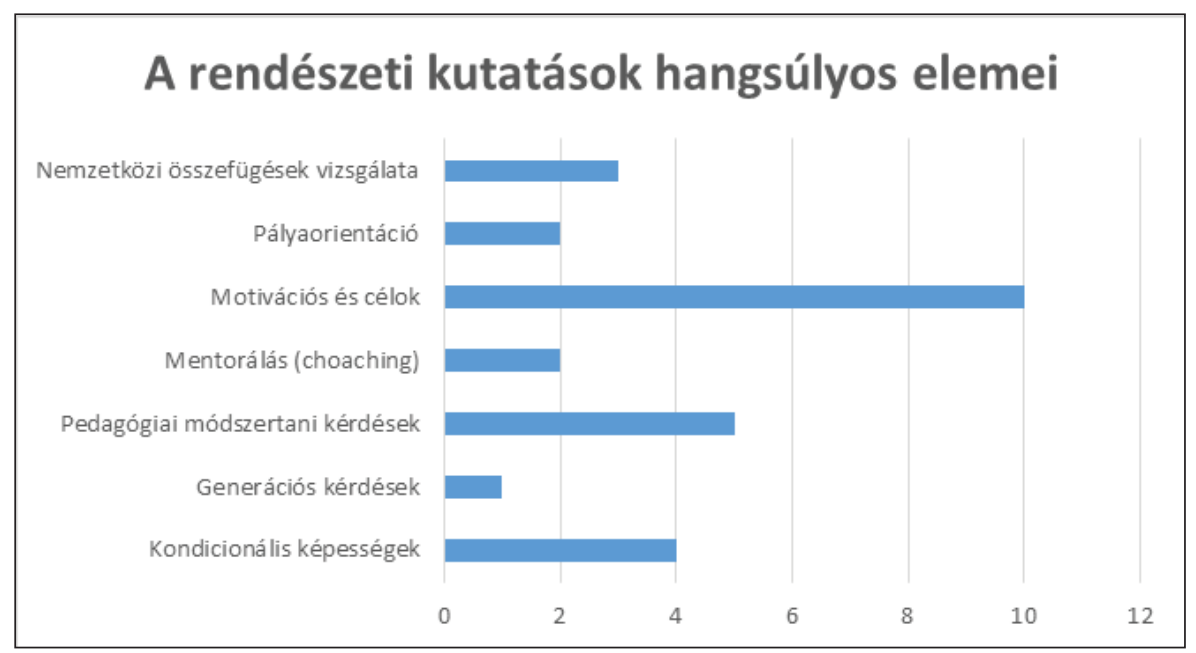

4. sz. diagram

A 4. sz. diagramm azt mutatja, hogy a rendészeti kutatások vonatkozásában készült munkák leginkább lényeges eleme a motivációk és célok témaköre, melynek vizsgálata részben összefügg a generációt érintő problémakör feltárásával, ami kihat a hallgatói inkorporációra. Másodikként a pedagógiai módszerek innovációs igénye jelenik meg, melynek szerves része az értékelés és oktatásmódszertani kérdések vizsgálata. A rendészeti szakterület kutatói és oktatói fontos elemnek tekintik a hallgatók fizikai, kondicionális képességeinek monitoringrendszerét. A nemzetközi vonatkozású cikkek összefüggéseinek vizsgálata három cikkben jelenik meg, ami az előzetes tájékoztatás és felvételi vonatkozásokat, a lemorzsolódást a leendő munkakör betöltésének relációjában érinti. A jelenlegi rendészeti felsőoktatási rendszerben osztályfőnöki rendszer működik, a mentorálás véletlenszerűen jelenik meg, melyre igény mutatkozik. A pályaorientáció is felmerül kérdésként, ami fontos része lehet a jövőbeni kutatásoknak. 


\section{Megbeszélés}

Javaslataink a jövőre nézve a következők; a motiváció rendkívül hangsúlyos terület a lemorzsolódást illetően, amely elválaszthatatlan összefüggésben áll a célokkal. A célok kapcsán elkerülhetetlen a személyes célok feltárása és az ahhoz vezető út tisztázása. Ez mind a polgári, mind pedig a rendészeti specifikációjú képzésben részt vevő hallgatók esetében vizsgálandó téma. Érdemes lenne a kutatást a hallgatói és a tanári oldalról is jobban, több szempont alapján elvégezni. Ennek egyik lehetősége a pedagógiai igények felmérése, ahogyan a hallgatók elvárásait is rendszeres időközönként érdemes monitorozni. Az igények figyelemmel kísérése és a szükségszerü pedagógiai megközelítési módok megválasztása javíthatja a megkapaszkodás eredményességét. A pályára irányítás hatékonyságának alapfeltétele, hogy konkrét elképzelés legyen azzal kapcsolatban, milyen kompetenciák mentén gondolkodik a megrendelő, tehát a szakma. A másik feltétel a széles körü, konkrét tapasztalati oldalról támogatott tájékoztatás, hogy a felvételre jelentkező leendő hallgatók releváns információk alapján tudjanak a szakmai területekre jelentkezni. Az egyetem rendészeti tagozata támogathatja a hallgatókat a pedagógiai módszerek helyes megválasztásával, így csökkentve a tanulmányi okok miatti lemorzsolódás kockázatát. A rendészeti munka egyik fontos alkotóeleme az olvasási és szövegértési készség magas szintjének megléte. Lehet, hogy ezt is vizsgálni kellene a jövőben. Lemorzsolódás leginkább veszélyeztetett időszakának behatárolása szintén fontos, hiszen azok a hallgatók, akik ekkor megkapják a kellő odafigyelést és elvárható segítséget, hálájukat kötődéssel és tanulmányaikkal, később szakmai eredményekkel honorálják. Figyelemmel a szakmai megrendelő igényeire érdemes lenne a gyakorlatorientált képzést erősíteni és a kiválasztás motoros képességeinek szintjeit és protokollját átgondolni. A hallgatók sport-, diákköri és egyéb szervezeti tagsága erősíti a kapcsolati tőkéjüket és ezáltal a megkapaszkodást az egyetemi életben, ezt is érdemes lenne a kutatások során vizsgálni.

\section{Konklúzió}

Kutatásunk fókuszában a Nemzeti Közszolgálati Egyetem rendészeti és más polgári egyetemek lemorzsolódásának összefüggései és szakirodalmi háttér vizsgálata állt. Valamennyi egyetemhez hasonlóan magas lemorzsolódási mutatókkal rendelkezik az intézmény. Az egyetemi pályaelhagyás problémája aktuális kérdés az eredményes működtetéshez, ezért a rendészeti szakok vezetése várja a megoldást erre az összetett kihívásra. Kutatásunk legfőbb célja volt, hogy a megfelelő módszertani protokoll mentén haladva feltárja az összefüggéseket, amelyek a rendészeti lemorzsolódást „'madártávlatból”, átfogó módon szemlélik, újszerű megközelítéseket és bővebb betekintést adnak számunkra, továbbá a tanulmányunkban olvasható összehasonlítások, értékelések és 
ajánlások által közelebb visznek a problémakör eredményes kezeléséhez. Az új generációk tulajdonságainak és igényeinek megismerése mentén, a fő irányelvek, kompetenciák és szakmai elvárások megtartása mellett lehetőség nyílik egy olyan új vezetői réteg kiművelésére, amely minden eddigi elvárást felülmúlva képes megfelelni a jövő európai, legmagasabb szintű rendészeti követelményeinek. Az egyetemi oktatók képzése és lemorzsolódása nem része jelen kutatásunknak, azonban érdemes lenne megvizsgálni a perzisztenciát az oktatók tekintetében is, akár a kiégés (burnout), akár a megbecsülési rendszer várható reformjának összefüggésében. A tapasztalatok azt mutatják, hogy az erősebb kiválasztáson átesett hallgatók jobb beilleszkedési esélyekkel indulnak, és stabilabb megfelelésről tanúskodnak. Ami még hangsúlyos a lemorzsolódás ellentételezéseként, az a támogató család és a baráti közösségek megléte, az új pozitív baráti kapcsolatok kialakítása. Így van ez a rendészeti területen is, ahol a hallgatók arról számolnak be egy hamarosan megjelenő tanulmányunk kapcsán, hogy az új közösséget az "új családjuknak” tekintik. Ez a kötődés és egymás iránti felelősségvállalás magas szintje, ami a hivatástudatban és csapatban való tevékenykedésben, valamint az ezzel összefüggő bajtársiasságban ölt testet.

\section{Szakirodalom}

Abári Kálmán, Balázs Katalin, Győrffy Ágnes, Hegedűs Judit, Horváth Ferenc, Hőgye-Nagy Ágnes, Kurucz Győző, Malét-Szabó Erika, Münnich Ákos, Németh Ferenc, Petró Csilla, Zalai Noémi (2014): (Szerk.) Hegedûs Judit. Tanulmánykötet a belügyi vezető-kiválasztási eljárásról pp 5-9. AROP-2.2.172012-2013-0001

Alter Emese (2019): A reziliencia és az egyetemi lemorzsolódás kockázatának vizsgálata leendő első generációs értelmiségiek körében, XI. Kiss Árpád Emlékkonferencia, Interdiszciplináris pedagógia múlt és jövő között, p 5. Kiadja: Kiss Árpád Archívum Könyvtára Debreceni Egyetem Nevelés- és Múvelődéstudományi Intézet, ISBN 978-963-490-125-9 Nyomta: Kapitális Kft., Debrecen

Csikósné Maczó Edit (2019): Online segítséggel a hallgatói lemorzsolódás ellen - A Dunaújvárosi Egyetem Avatar-programjának bemutatása, Képzési Gyakorlat, 2019. 17. évfolyam 1. szám, https://doi.org/10.17165/TP.2019.1.7

D. Molnár Éva - Gál Zita (2019): Egyetemi tanulmányaikat megkezdő hallgatók tanulási mintázata és tanulói profilja. Iskolakultúra, 29. évfolyam, 2019/1. szám pp 29-41.

https://doi.org/10.14232/ISKKULT.2019.1.29 
Detre Zoltán, Tibeszkyné dr. Fórika Krisztina (2011): Tisztjelölt hallgatók fizikai alkalmasság mérésének tapasztalatai és információtechnológiai támogatásának lehetőségei, Az NKE HHK Tudományos Folyóirata, Budapest, 2011. 4. évfolyam 4. szám pp 123-127.

Doung Van Thinh (2016): A mentor rendszer szerepe a felsőoktatásban, Vállalkozásfejlesztés a XXI. században Budapest, 2016 pp 65 -82.

Dunai Pál (2013): Repüléstudományi közlemények, XXV. évfolyam 2013. 2. szám, Online tudományos folyóirat, pp 498-503.

Fenyves Veronika, Bácsné Baba Eva, Szabóné Szőke Réka, Kocsis Imre, Juhász Csaba, Máte Endre, Pusztai Gabriella (2017): Kísérlet a lemorzsolódás mértékének és okainak megragadására a Debreceni Egyetem Gazdaságtudományi Kar példáján, Neveléstudomány, pp 5-14. https://doi.org/10.21549/NTNY.19.2017.3.1

Hegedűs Judit, Sipos Szandra, Molnár Katalin (2016): Hegedűs Judit (szerk.) A magatartástudomány helye és szerepe a rendészeti képzésben, Szemléletformálás a rendészeti képzésben, Az osztályfőnöki rendszer a rendészeti felsőoktatásban, A motiválás módszertani lehetőségei a felsőfokú rendészeti képzésben-korlátok, kihívások, lehetőségek Nemzeti Közszolgálati Egyetem, Budapest A kiadvány a KÖFOP-2.1.2-VEKOP-15-2016-00001 azonosítószámú, "A jó kormányzást megalapozó közszolgálat-fejlesztés" címü projekt keretében készült el és jelent meg. pp 46-60.

Józsa Gabriella (2018): Lemorzsolódási kockázatok a felsőoktatásba kerülés előtt, Educatio 27 (4), pp. 700-710. (2018) https://doi.org/10.1556/2063.27.2018.4.12

Józsa Gabriella (2019): Lemorzsolódási rizikófaktorok a felvételi adatbázis alapján, Iskolakultúra, 29. évfolyam, 2019/2-3. szám pp 3-21. https://doi.org/10.14232/ISKKULT.2019.2-3.3

Kamarási Viktória, Mogyorósy Gábor (2015): Szisztematikus irodalmi áttekintések módszertana és jelentősége, Segítség a diagnosztikus és terápiás döntésekhez, Orvosi Hetilap, 2015. 156 (38) pp 1523-1531. https://doi.org/10.1556/650.2015.30255

Kovács Karolina Eszter (2018): A motiváció szerepe a felsőoktatási lemorzsolódásban és perzisztenciában, Iskolakultúra, 28. évfolyam, 2018/1011. szám, pp 55-63. https://doi.org/10.14232/ISKKULT.2018.10-11.55

Kovács Klára - Ceglédi Tímea - Csók Cintia - Demeter-Karászi Zsuzsanna - Dusa Ágnes Réka - Fényes Hajnalka - Hrabéczy Anett - Kocsis Zsófia - Kovács Karolina Eszter - Markos Valéria - Máté-Szabó Barbara - Németh Dóra KatalinPallay Katalin - Pusztai Gabriella - Szigeti Fruzsina - Tóth Dorina Anna - Váradi Judit (2019): Lemorzsolódott hallgatók. In: OKTATÁSKUTATÓK KÖNYVTÁRA 6. Debrecen, 2019. 
Kristóf Zsolt (2019): Recenzió, Pusztai Gabriella, Szigeti Fruzsina (szerk.): Lemorzsolódás és perzisztencia a felsőoktatásban, Debreceni Egyetemi Kiadó, 2018.

Lendvai Edina, Panyor Ágota, Hampel György (2019): A mérnöki kar agrár és műszaki képzési területein történő lemorzsolódás okainak feltárása tárgyában készült kérdőíves felmérés eredményei, Jelenkori társadalmi és gazdasági folyamatok, (2019) XIV. évfolyam, 1. szám, pp 205-210. https://doi.org/10.14232/jtgf.2019.1.205-210

\section{Levelező szerző:}

Mácsár Gábor

Eszterházy Károly Egyetem, Doktori Iskola, Eger macsarekszer@gmail.com 